\title{
Valuing Water Resources in Turkey: A Case Study of Beyşehir Lake
}

\author{
Lelia Croitoru', Buket Bahar Divrak ${ }^{2}$, Jian Xie ${ }^{1}$ \\ ${ }^{1}$ The World Bank, Washington DC, USA \\ ${ }^{2}$ The World Bank, Ankara, Turkey \\ Email:1croitoru@worldbank.org
}

How to cite this paper: Croitoru, L., Divrak, B.B. and Xie, J. (2016) Valuing Water Resources in Turkey: A Case Study of Beyşehir Lake. Journal of Environmental Protection, 7, 1904-1922.

http://dx.doi.org/10.4236/jep.2016.712150

Received: October 21, 2016

Accepted: November 26, 2016

Published: November 29, 2016

Copyright $\odot 2016$ by authors and Scientific Research Publishing Inc. This work is licensed under the Creative Commons Attribution International License (CC BY 4.0).

http://creativecommons.org/licenses/by/4.0/ (c) (i) Open Access

\begin{abstract}
Water resource management is critical to Turkey's economy and environment. The country has about 112 billion $\mathrm{m}^{3}$ per year of economically exploitable water. However, population growth, climate change and pollution of water bodies are putting increasing pressure on these resources. In this context, understanding the contribution of water to the economy and environment is crucial for its conservation. To meet this need, the World Bank launched a program aiming at improving valuation and accounting systems of natural resources in Turkey. As part of this program, this article estimates in monetary terms the economic value of water in Beyşehir Lake, the largest freshwater lake in Turkey. Valuation is based on the Total Economic Value concept, which includes use and non-use values. The results show that the economic value of water is about seven times higher than its financial value. In addition, the economic value of water allocated for municipal use $\left(\mathrm{TL} 5 / \mathrm{m}^{3}\right)$ is substantially greater than that supplied for irrigation $\left(\mathrm{TL} 0.5 / \mathrm{m}^{3}\right)$. The analysis suggests that allocation of water from Beyşehir Lake among different uses is inefficient. To validate this conclusion and improve allocation, a more comprehensive assessment of the economic benefits of water resources is needed, particularly of water supply for irrigation, municipal use, recreation and biodiversity. The analysis also indicates that economic valuation can be a powerful tool to improve water management at the river basin level.
\end{abstract}

\section{Keywords}

Water Valuation, Total Economic Value, Beyşehir Lake

\section{Introduction}

Water is among the most important natural resources in Turkey. The country's annual 
average potential of economically exploitable water resources is ${ }^{1} 112$ billion $\mathrm{m}^{3}$ [1]. Annual freshwater consumption is about 44 billion $\mathrm{m}^{3}$, of which $74 \%$ is used for agriculture, $15 \%$ for domestic needs and $11 \%$ for industrial uses. In addition to its contribution to economic production, water and its related ecosystems (e.g. lakes, wetlands, coastal zones, etc.) provide a wide range of benefits such as flood protection, pollution abatement and biodiversity conservation.

Despite its importance, water is facing several threats. Population growth and natural factors, such as climate change, are expected to reduce water availability in many areas. This is particularly important for basins such as Marmara Basin, K. Menderes Basin and Asi Basin, where water availability per capita is already less than $1000 \mathrm{~m}^{3} /$ capita $^{2}$. In addition, water pollution (e.g. by untreated industrial wastewater discharge in receiving water bodies) could induce a significant reduction in water quality. In this context, conserving the quantity and quality of water resources is essential for the country's long-term growth and sustainability.

Understanding water's contribution to the economy and environment is a crucial step towards its conservation. Worldwide, existing literature is extremely diverse in terms of types of water values estimated. Most studies focus on estimating values related to surface water, with the majority concentrating ona single water service, such as: water supply for irrigation, e.g. [4] [5]; for domestic use, e.g. [6]; for industrial use, e.g. [7]; recreational value, e.g. [8] [9] [10]; flood control, e.g. [11] [12]; and marine biodiversity, e.g. [13] [14]. A significant number of studies however value two or more services of water resources, e.g. [15] [16] and a small number estimate the TEV of all water services, e.g. [17]. Substantially less work attempts to estimate values related to groundwater, most of which addresses the cost of groundwater depletion [18] [19], and the benefits of improving groundwater quality, e.g. [20].

Similarly, in Turkey, the economic value of water benefits is only partly known. Existing studies usually focus on estimating the recreational value of water in nature parks (e.g. [21] [22]), protected areas (e.g. [23]) and coastal areas (e.g. [24] [25] [26]). Fewer efforts estimate the value of water quality improvements, in relation to lakes (e.g. [27] [28]), coastal areas (e.g. [29]), and marine environment (e.g. [30]); and even fewer assess the value of water uses, such as agriculture (e.g. [31] [32]), hydropower (e.g. [33]), municipal use (e.g. [34]), or of all uses combined (e.g. [35]). Only one study was found to estimate the total economic value (TEV) of water resources [36]. Thus, existing literature suggests that efforts to value direct uses (e.g. agriculture, industry, municipal use), indirect uses (e.g. pollution abatement) and non-use values (e.g. biodiversity) of water are scarce in Turkey.

This scarcity of valuations emphasizes the need of economic valuation of each water

${ }^{1}$ Other sources provide other estimates. For example, FAO indicates a total renewable water resource of about 227 billion $\mathrm{m}^{3}$ [2]. However, this article uses 112 billion $\mathrm{m}^{3}$, as it is the official estimate generated by the General Directorate of State Hydraulic Works, which takes into account the current technical and economic constraints.

${ }^{2}$ These basins are mainly concentrated in the western and central parts of the country, where highly populated and industrial cities are located [3]. 
use as a precondition for making well-informed decisions on water-related policies. Aware of this importance, the Government of Turkey is making steady efforts to improve water valuation and accounting. To support this interest, the World Bank launched a Natural Capital Accounting program, which aims at improving the valuation and accounting systems of natural resources in Turkey. As part of the program, this article provides a methodology to estimate the value of the economic benefits related to water, and applies it in a rapid economic valuation of water benefits in a pilot area: Beyşehir Lake.

\section{The Case Study Area: Beyșehir Lake Sub-Catchment}

Beyşehir Lake is the largest freshwater lake in Turkey. It is located in the southwestern corner of Konya Closed Basin, situated in the Central Anatolian Plateau (Figure 1). The Basin has semi-arid climate conditions and an annual average precipitation of around $300-350 \mathrm{~mm}$, which is almost half of Turkey's average. Beyşehir Lake subcatchment has an area of about 414,000 ha, and the lake itself has a water surface of about 73,000 ha (Figure 2).

The lake's southern and northern shores are shallow and mostly covered with swamp and reedbeds. Forested mountains in the west and south border the lake, with lower parts of the maquis-covered slopes occupied by small areas of arable land and orchards. In the north of the lake, there is the indigenous Cedrus forest of Kizlldağ, whereas the eastern side is flat, and mainly used for crop cultivation.

Beyşehir Lake lies within the administrative boundaries of Isparta and Konya provinces. There are five major settlements located in the sub-catchment: Beyşehir,

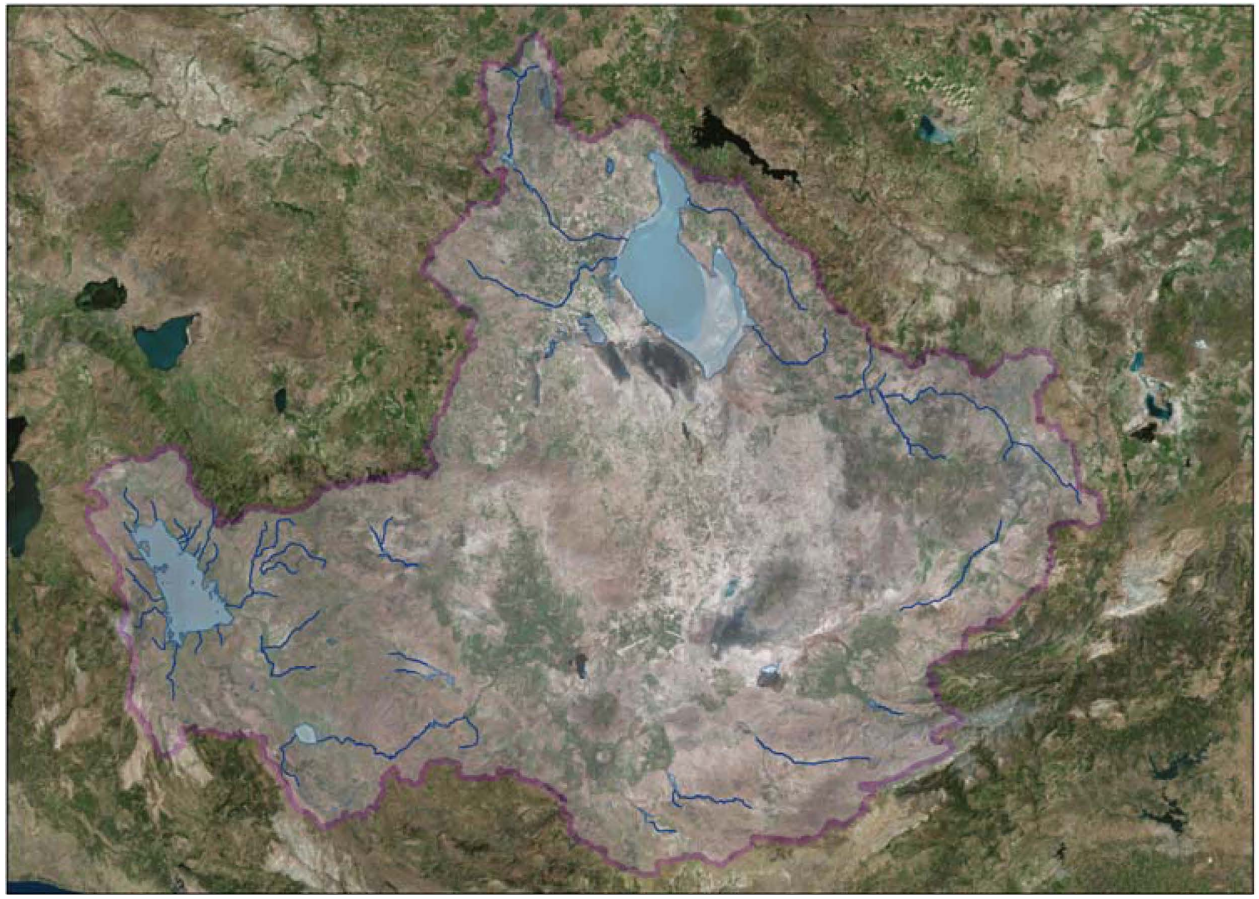

Figure 1. Konya Closed Basin. Source: [37]. 


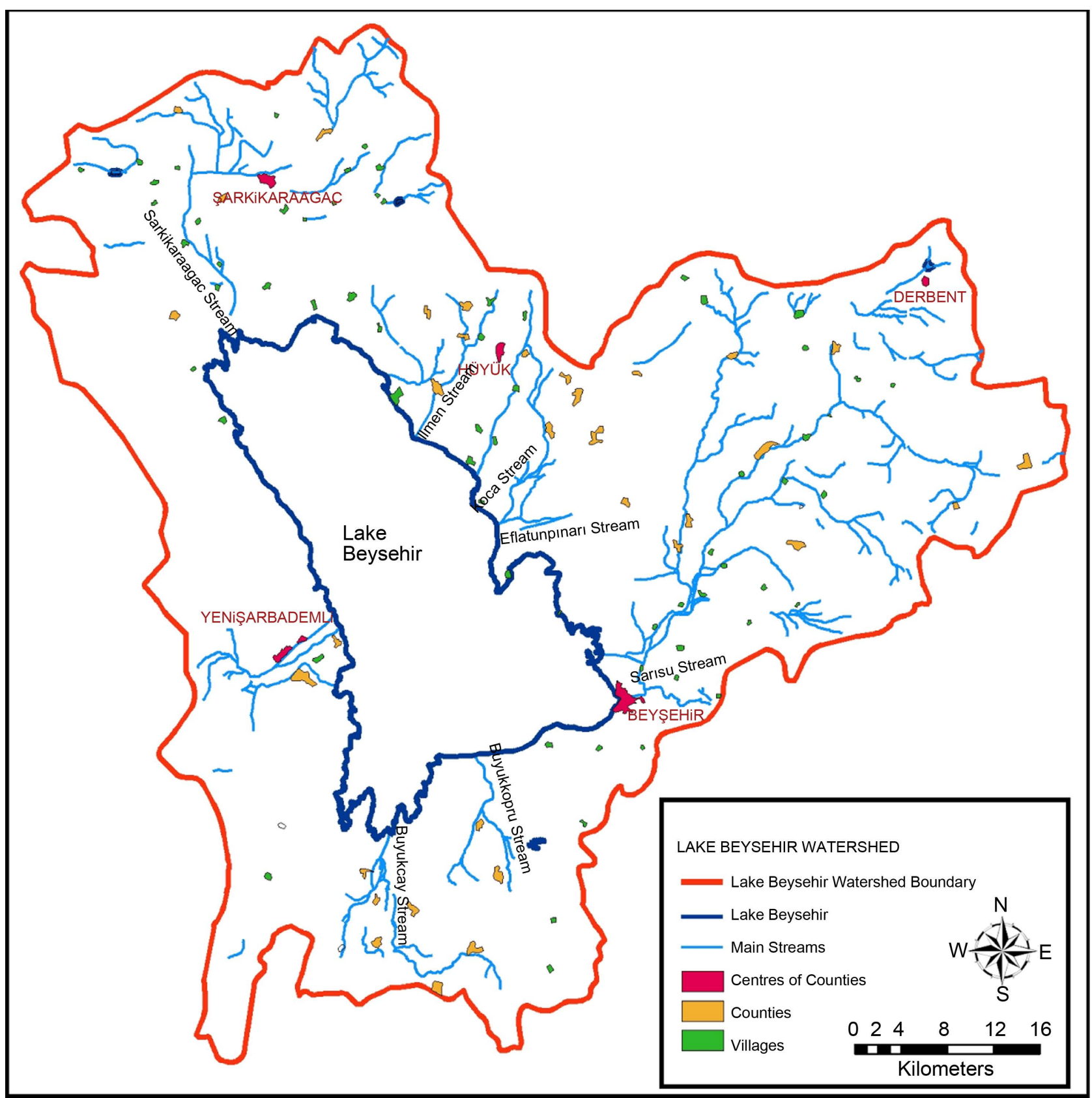

Figure 2. Beyşehir Lake sub-catchment. Source: [38].

Hüyük, Derbent, Yenişarbademli and Şarkikarağaç, with a total population of 120,000 [39]. Agriculture (crop production and livestock), fisheries, and tourism are the main economic sectors in the sub-catchment. Of these, agriculture is the most important, and consists of both irrigated agriculture and dry land arable farming. Water from the lake is mostly used for irrigating Konya Plain and other irrigation projects developed by DSI (Şarkikarağaç and Kıreli) and as a source of drinking water in the five settlements. In addition, the lake is a designated national park, with rich biodiversity, in terms of waterfowl (Netta rufina, Aythya ferina, Fulica atra) and fish species (Cyprinus carpio, 
Sander lucioperca, Carassius gibelio, Tinca tinca, Atherina boyeri) [40].

Despite these benefits, several problems affect the lake. The most pressing issue is the decreasing water levels due to water over-abstraction for irrigation. According to long-term statistics, the lake's water level has fallen dramatically, reaching an area of only 50,000 ha in dry seasons. With the increased demand for water and climate change, Beyşehir Lake can be at serious risk of reaching critical water levels in the near future. Furthermore, decreasing water levels may also result in changes in the lake's water quality parameters, such as turbidity, suspended sediment, and chlorophyll-a [38].

\section{Methodology}

Valuation of the economic benefits of water is based on identifying the main types of water values, then estimating them through appropriate valuation methods. Identifying the main types of water values is based on the TEV framework, which includes use and non-use values (Figure 3).

Use values are benefits derived from the actual water use, and comprise three types of values:

1) Direct use values, which arise from direct interaction with aquatic resources and include: water supply (e.g. for irrigation, municipal uses and industrial uses), recreation (e.g. swimming, diving, boating) and industrial uses (e.g. beverage and food industry, hydropower, navigation), wildlife and plant harvesting (e.g. fishing, algae, shells).

2) Indirect use values, which are benefits associated with services provided by aquatic resources, without entailing direct interaction. These include nutrient retention (i.e. the capacity of water bodies to retain excess nutrients), pollution control (i.e. the ability of the ecosystem to trap sediments and retain pollutants), flood control (i.e. the ecosystem's ability of capturing, storing, and slowly releasing water over time, thus reducing the

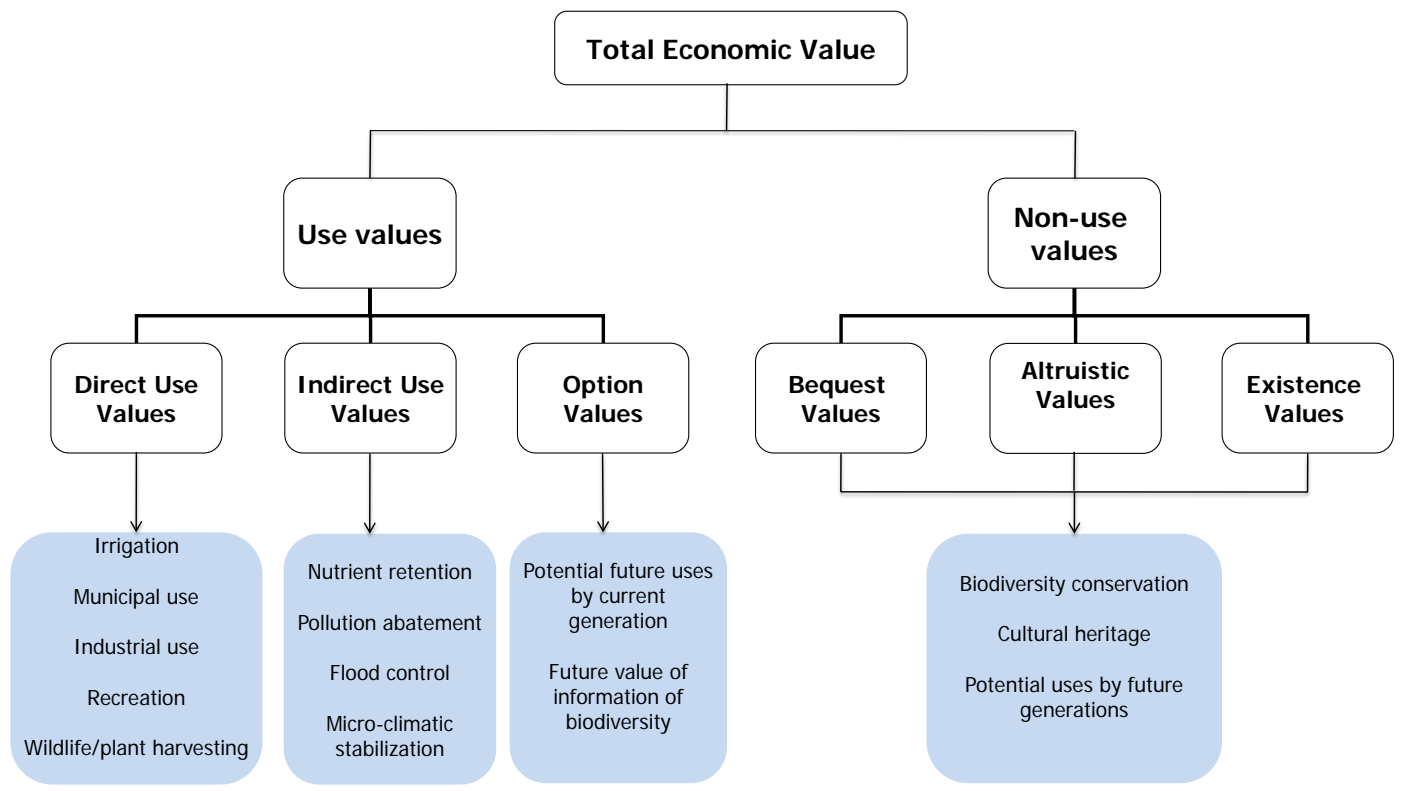

Figure 3. TEV of water resources. Sources: adapted from [13] [41] [42]. 
occurrence of floods) and micro-climatic stabilization (i.e. the capacity to stabilize climatic conditions such as an area's temperature and humidity).

3) Option values are benefits originating from having the option of using water resources in the futureand include: potential future uses of direct and indirect uses (e.g. recreational opportunities, fish consumption) and future value of information related to biodiversity (e.g. potential future use of plants as inputs in the production of pharmaceuticals).

Non-use values are benefits unrelated to the current use values, but reflect the economic value that can be attached to the mere existence of a water-related aspect. They can be divided in three types of value, which may overlap:

4) Existence values refer to the values individuals may place upon the conservation of water resources, though they may never use them directly themselves. They can include conservation of certain species of fish or mammals, and preservation of a site for its cultural value.

5) Bequest values, related to the values that individuals place for a future generation's opportunity to enjoy an aquatic resource.

6) Altruistic values, related to the fact that even if individuals themselves do not use or intend to use the aquatic ecosystem, they may still be concerned that the environmental good in question be available to others in the current generation [13].

Estimating the different types of water values can be based on a wide variety of methods. These range from market-based approaches (e.g. market pricing, replacement cost, avertive expenditures) to revealed preferences (e.g. Travel Cost, Hedonic Pricing, residual method, productive functions), stated preference methods (e.g. Contingent Valuation Method and Choice Experiments) and benefits transfer. Detailed description of each valuation method can be found in several publications, e.g. [41] [43]-[48].

It should be noted that the choice of a specific valuation method depends on several factors: type of values to be estimated (i.e. while use values can be estimated through most available techniques, non-use values can only be estimated through stated preference methods); purpose of valuation (i.e. certain purposes require valuation techniques based on the estimation of marginal values, while others require valuation of total or average values); data availability (i.e. existence of data from secondary resources); resources and time available (i.e. the techniques can differ greatly in terms of the resources and time required to undertake a study).

Table 1 introduces the types of values and the main valuation methods used to estimate the TEV of Beyşehir Lake. Data collection was based on secondary information gathered from scientific articles, complemented by interviews with local authorities during field visits conducted during the spring of 2016. Locally available information relates mostly to tangible goods, e.g. areas, yields, and local prices. However, a detailed valuation study could not be conducted due to limited time and resources for the study, which, inevitably, creates a degree of uncertainty. Because of this reason, some benefits were approximated by transferring unit values from other similar contexts, as in the case of water for municipal use and non-use values. Others, 
Table 1. Beyşehir Lake: TEV and valuation methods.

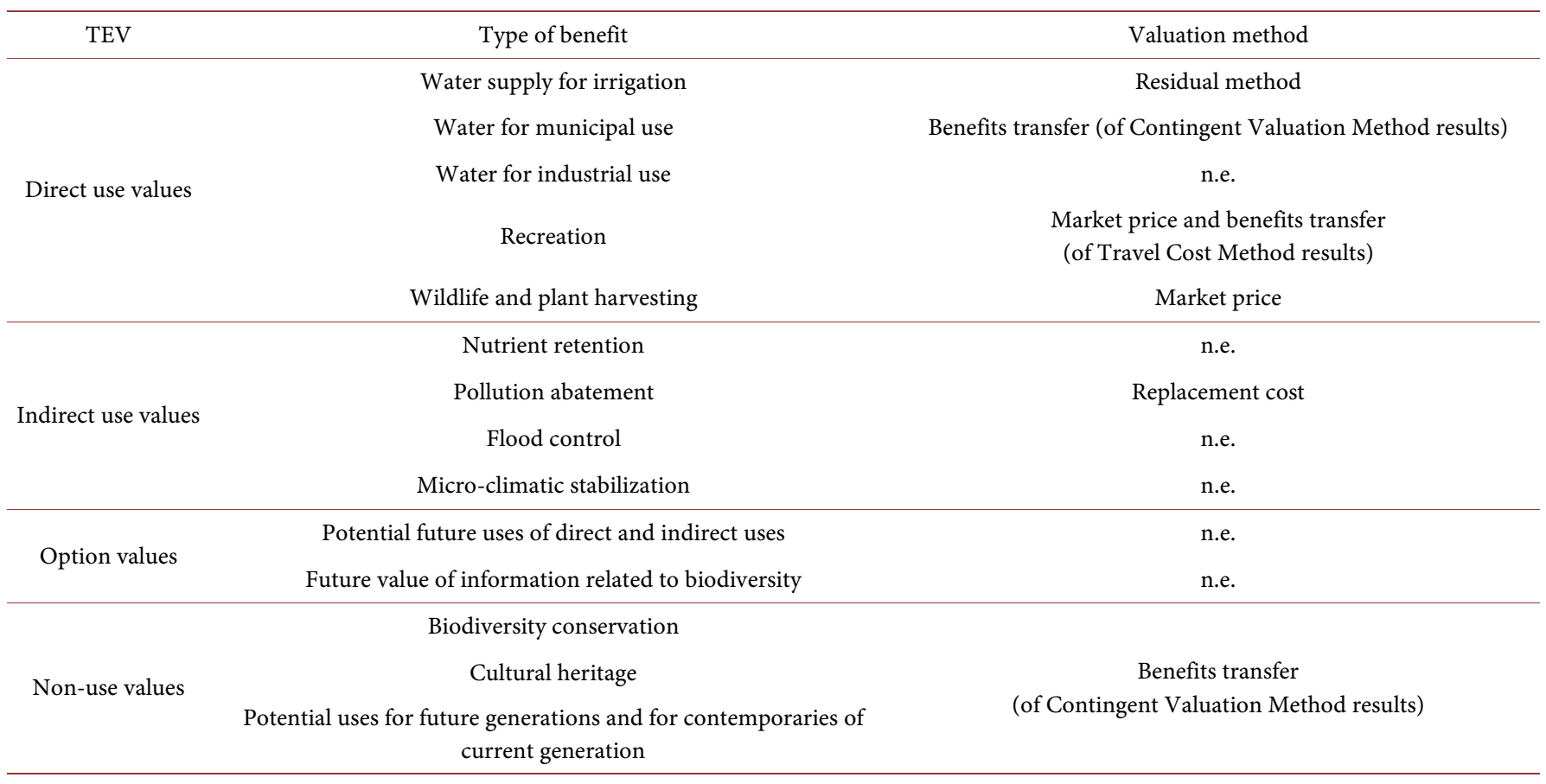

n.e. $=$ not estimated.

such as the value of water for agriculture, could be estimated using results of farm budgets that account only for marketed inputs (e.g. cost of fertilizers, harvest), and omit the non-priced ones (e.g. cost of unpaid labor). Yet, some other benefitscould not be estimated at all, such as the value of nutrient retention, flood control and microclimatic stabilization. Because of these limitations, the final resultsshould be considered only orders of magnitude that only approximate the real value of these benefits.

\section{Results}

This section describes the valuation of benefits provided by Beyşehir Lake. It estimates the gross value of these benefits for the year 2015 and presents the results in Turkish Lira (TL1 = US $\$ 0.34)$. The results are grouped among direct use values, indirect use values and non-use values related to the lake.

\subsection{Direct Use Values}

Water supply for irrigation. Water from Beyşehir sub-catchment is largely used for irrigated agriculture. In 2015, about 347 million $\mathrm{m}^{3}$ of water ${ }^{3}$ has been used to irrigate 64,490 ha of agricultural land. Around $56 \%$ of the irrigated area is located in Beyşehir sub-catchment, and the rest in Çumra region. Table 2 presents the main information related to the crops cultivated in these areas.

${ }^{3}$ About 320 million $\mathrm{m}^{3}$ originated from Beyşehir Lake and 27 million $\mathrm{m}^{3}$ from the groundwater of Beyşehir sub-catchment. As it is not possible to distinguish among crops according to the irrigation sources, the present valuation considers all crops irrigated with water from both the lake and from the groundwater of Beyşehir sub-catchment. 
Table 2. Irrigated crops with water from Beyşehir Lake (2015).

\begin{tabular}{|c|c|c|c|c|c|c|c|}
\hline Crops & $\begin{array}{c}\text { Area } \\
\text { (ha) }\end{array}$ & $\begin{array}{l}\text { Yields } \\
(\mathrm{t} / \mathrm{ha})\end{array}$ & $\begin{array}{c}\text { Price } \\
(\mathrm{TL} / \mathrm{kg})\end{array}$ & $\begin{array}{l}\text { Agricultural revenue } \\
\qquad(\mathrm{TL} / \mathrm{ha})\end{array}$ & $\begin{array}{l}\text { Net water use } \\
\left(\mathrm{m}^{3} / \mathrm{ha}\right)\end{array}$ & $\begin{array}{l}\text { Total water used } \\
\left(\text { million } \mathrm{m}^{3}\right)\end{array}$ & $\begin{array}{l}\text { Water tariff } \\
\text { (TL/ha) }\end{array}$ \\
\hline & (a) & (b) & (c) & $=(b)^{*}(c)$ & (d) & $=(\mathrm{a})^{\star}(\mathrm{d})$ & (e) \\
\hline \multicolumn{8}{|l|}{ Beyşehir sub-catchment } \\
\hline Wheat & 7620 & 4.7 & 0.9 & 4000 & 4500 & 34.3 & 120 \\
\hline Sugarbeet & 3740 & 59.5 & 0.7 & 11,300 & 8000 & 29.9 & 220 \\
\hline Fruit trees & 940 & 31.3 & 0.8 & 24,400 & 6000 & 5.6 & 360 \\
\hline Strawberries & 480 & 35.6 & 0.8 & 26,700 & 5000 & 2.4 & 360 \\
\hline Sub-total Beyşehir & 30,480 & n.a. & n.a. & 4700 & 4700 & 143.0 & 143 \\
\hline Maize & 7750 & 9.6 & 0.6 & 6100 & 7000 & 54.2 & 220 \\
\hline Sugarbeet & 9250 & 77.4 & 0.2 & 14,700 & 8000 & 74.0 & 220 \\
\hline Sunflower & 1600 & 4.5 & 0.9 & 3900 & 6000 & 9.6 & 140 \\
\hline Sub-total Çumra & 34,010 & n.a. & n.a. & 7160 & 5990 & 203.6 & 171 \\
\hline Total & 64,490 & n.a. & n.a & 5990 & 5380 & 346.6 & 158 \\
\hline
\end{tabular}

Sources: [49] for area and yields; [50] for crop prices; communication with Konya agricultural directorate for the net water use; communication with the regional directorate of the general directorate of State hydraulic works (Devlet Su İsleri, DSI) for water tariff; n.a. = not applicable. Note: the results may not add up exactly due to rounding.

To estimate the economic value of water, we use the residual method $[43]^{4}$ : first, we estimate for each regionthe costs of production unrelated to water (e.g. fertilizers, soil preparation, planting, pesticides, maintenance, rent, etc.); then we subtract these costs from the agricultural revenue and attribute the difference to the value of water. These data, obtained from simple farm budgets ${ }^{5}$, are summarized in Table 3. Accordingly, the economic value of water is estimated at TL186 million.

Water supply for municipal use. Beyşehir Lake provides 11 million $\mathrm{m}^{3}$ of water for municipal use (communication with the $7^{\text {th }}$ Regional Directorate of KOSKI). It serves ${ }^{4} \mathrm{An}$ alternative way to estimate this benefit is by ascribing the difference between the unit value of irrigated and non-irrigated land to the value of water. However, applying this method could be problematic for this area, because irrigated land is covered by several crops (wheat, barley, sugarbeet, strawberries, fruit trees, etc.), while non-irrigated land is cultivated only with wheat. In this case, the difference between the revenue of an average hectare covered by several high-value added crops and that of a hectare covered by rainfed wheat could not be attributed solely to the input of water (much of the difference results from other production inputs). At the same time, the difference between the revenue of a hectare cultivated with irrigated and non-irrigated wheat would underestimate the benefit of water used for other high value crops. Because of the above limitations, this section uses the residual method to estimate the value of water for irrigated agriculture.

${ }^{5}$ Based on Konya Provincial Directorate of Agriculture, these farm budgets relate to the year 2015 and refer to irrigated wheat (33 farms, $2540 \mathrm{ha}$ ), rainfed wheat (33 farms, $2404 \mathrm{ha}$ ), irrigated barley ( $47 \mathrm{farms}, 4767 \mathrm{ha}$ ), sunflower (24 farms, $1736 \mathrm{ha}$ ), maize (20 farms, $2058 \mathrm{ha}$ ) and sugar beet (56 farms, $2734 \mathrm{ha}$ ). The main cost items cover soil preparation, planting, fertilizers, pesticides, irrigation, maintenance, harvesting, land rent and other fixed costs. 
Table 3. Estimated economic value of water for agriculture (million TL, 2015).

\begin{tabular}{lccc}
\hline \multicolumn{1}{c}{ Estimated values } & Beyşehir & Çumra & Total \\
\hline Agricultural revenue (1) & 143 & 243 & 386 \\
Cost of production & 83 & 150 & 233 \\
-Water-related costs & 4 & 29 & 33 \\
-Other costs (2) & 78 & 122 & 200 \\
Economic value of water for irrigation $(1-2)$ & 65 & 121 & 186 \\
\hline
\end{tabular}

Sources: [51] for farm budgets of irrigated lands in Çumra; communication with agricultural officer of the Konya Provincial Directorate of Agriculture for Beyşehir.

71,400 people, distributed among 42,700 subscribers. These include 34,100 households and 8600 commercial establishments. According to the $7^{\text {th }}$ Regional Directorate of KOSKİ in Beyşehir, households consume on average about $18 \mathrm{~m}^{3} /$ month. Consequently, water consumption is estimated at 7.4 million $\mathrm{m}^{3}$ for households and 3.6 million $\mathrm{m}^{3}$ for commercial establishments.

The tariff for municipal water is $\mathrm{TL} 2.3 / \mathrm{m}^{3}$ for households and $\mathrm{TL} 3.5 / \mathrm{m}^{3}$ for commercial establishments. However, since these are nominal values, they do not represent the society's willingness to pay (WTP) for tap water. No study estimating the economic value of municipal water has been found for the pilot area. However, the WTP for municipal water was estimated to be $85 \%$ higher than the actual water tariff in Greater Baku, Azerbaijan (AZN15.1 vs. AZN8.3/m³) [52] and about twice as much as in Bursa, Turkey (TL32 vs. TL16/ $\mathrm{m}^{3}$ ) [35]. Assuming that the economic value for municipal water in Beyşehir is only 85\% higher than its nominal value (as in Baku), it is estimated at TL4.3/ $\mathrm{m}^{3}$ for households and TL6.5/ $/ \mathrm{m}^{3}$ for commercial households. These estimates are in the same range with the WTP for potable water found in Southeastern Turkey, of TL6.4/ $\mathrm{m}^{3}$ [34]. Applying these values to the total consumption of municipal water in Beyşehir sub-catchment, the economic value of municipal waterreaches TL55 million.

Water supply for industrial use. Several small- and medium-scale industries exist in Beyşehir sub-catchment related to food and fish processing, weapons and ammunition production, textile and chrome processing. The towns Huğlu and Üzümlü are well known for their rifle factories, which export $80 \%$ of Turkey's shotgun products to more than 50 countries around the world (interview with local experts). However, no data is available on the use of water for these industries, therefore no estimate can be provided at this stage.

Recreation. The landscape characteristics of Beyşehir Lake and the neighboring national parks (Beyşehir and Kızıldağ) are sources of several recreational activities, such as bird watching, swimming, sports fishing, and water surfing. In addition, cultural and historical heritage sites make Beyşehir Lake a popular weekend destination for people living in Konya and other nearby settlements. Overall, there are about 327,900 visitors per yearto Beyşehir Lake (Table 4). According to data gathered from national park management units, about 102,900 visitors have been recorded paying entrance fees in different areas. The remaining 225,000 are enjoying the lake free of charge. The following 
Table 4. Number of visitors in different areas of Beyşehir Lake (2015).

\begin{tabular}{lcccc}
\hline \multicolumn{1}{c}{ Visitors } & Karaburun beach $^{\mathrm{a}}$ & Yakamanastır Nature Park & & \\
& & Kizıldağ National Park & Total \\
\hline -Paying entrance fees & 42,300 & 42,200 & 18,400 & 102,900 \\
-Free of charge & & 200,000 & 25,000 & 225,000 \\
Total & 284,500 & 43,400 & 327,900 \\
\hline
\end{tabular}

Note: ${ }^{a}$ Part of Beyşehir Lake National Park. Source: Communications with Beyşehir Lake National Park and Kızıldağ National Park management units.

paragraphs estimate the recreational benefit for both types of visitors.

1) Recreational benefits for visitors paying entrance fees. These benefits include the actual payments made by these individuals to visit the park, and the consumer surplus they enjoy in addition to their actual payment. They are estimated as follows:

- Actual payments. According to Beyşehir Lake National Park management unit, the entrance fee is TL3/visit; this leads to a total amount paid at the entrance of TL308,600. In addition, there are three sightseeing cruise boats in the lake, each transporting about 100 passengers/day from mid April-mid October at a price of TL7.5/person. The revenues collected from boating activities are estimated at TL405,000. Consequently, revenues gathered from entrance fees and boating amount to TL713,600.

- Consumer surplus. The value associated with these benefits has not been estimated for Beyşehir Lake. However, several studies have been conducted in relation to other lakes in Turkey. Examples include efforts conducted in Kursunlu Waterfall Nature Park in Antalya province [21], Great Meander Delta National Park, on the Aegean coast [22], Lake Manyas of Kuşcenneti National Park [27] and Tuz Lake Specially Protected Area, located within the borders of Konya Closed Basin [23]. Among these areas, Lake Manyas of Kuşcenneti National Park provides the most similar context to that of Beyşehir Lake, as both are large inland freshwater lakes with similar characteristics. Based on this study, the consumer surplus is estimated at about TL17.8/visit (in 2015 prices). Applying this value to the number of visitors paying entrance fees in Beyşehir (102,900), the consumer surplus is estimated at TL1.8 million.

Based on the above calculations, the recreational benefit of visitors paying entrance fees totals TL2.5 million (1).

2) Recreational benefits for visitors that come free of charge. Although these visitors do not pay any fees to the park, they benefit from several services such as landscape views, picnicking and swimming. These benefits have not been estimated for Beyşehir Lake; in lack of information, we assume that they are similar to the consumer surplus estimated for the visitors that pay entrance fees, i.e. TL17.8/visit. Accordingly, the recreational benefit for visitors arriving free of charge (225,000 people) is estimated at TL4 million (2).

Adding up the estimates obtained for all visitors $(1+2)$, the total recreational benefit is estimated at TL6.5 million in 2015. 
Fishing. Fishing is the main source of income for several settlements located around the lake. During 2000-2015, this activity declined significantly from 2000 licensed fishermen with a total catch of 1400 - 1600 tons [53] to only 680 licensed fishermen with 256 tons catch. The lake is divided into two fishing zones: Sarkikaraagac fishing zone, located in Isparta province, and Beyşehir fishing zone, situated in Konya province. Data collected from experts at Konya Provincial Directorate of Agriculture indicate thatthe most common fish caught in 2015 was pikepearch (135 tons), followed by carp (105 tons) and silver crucian carp (16 tons). Local market prices are TL14/kg of pikepearch, TL12/kg of carp and TL1/kg of silver crucian carp. Accordingly, the value of fish catch is estimated at TL3.1 million. In addition, an interview with experts at Şarkikaraağaç District Directorate of Agriculture suggested that in reality, the unlicensed fish catch is at least twice the quantity of fish caught legally. Accordingly, the real value of fishing is estimated at TL9 million.

Reed cutting. Reed cutting was a source of income in the pilot area until 2010. However, decreasing water levels and shrinking of the lake led wild boars to infest the lands and destroy the reed beds. Nowadays, the quality of reeds does not meet the required standard for export and local people harvest them only for traditional uses such as roofing. No information is available to estimate the local value of reeds extracted from around the lake.

\subsection{Indirect Use Values}

Pollution abatement. The lake is considered to be important in performing water purification functions. According to local water authorities, the settlements of Derbent (4600 people), Hüyük (16,300 people), and Şarkikaraağaç (25,800 people) do not benefit from operational wastewater treatment plants, so their residents discharge untreated wastewater in the streams flowing into Beyşehir Lake. The average discharge quantity is about 90 liters/capita/day in the region ${ }^{6}$. Based on the above, the total quantity of municipal wastewater discharged from these settlements amounts to 1.5 million $\mathrm{m}^{3}$.

The pollution abatement function is estimated through the replacement cost method, assuming the cost of wastewater treatment in the area. The annual cost of advanced wastewater treatment is estimated at $\mathrm{TL} 1.8 / \mathrm{m}^{3}$ of wastewater, based on information from $\operatorname{KOSKI}^{7}$. Applying this cost to the quantity of untreated municipal water discharged in streams flowing in Beyşehir, the total replacement cost is estimated as TL2.8 million. Other indirect use values such as nutrient retention, flood control and microclimatic stabilization could not be estimated, due to the non-market nature of these benefits and data scarcity.

\subsection{Non-Use Values}

This section estimates the value of biodiversity as a non-use value. In other words, this ${ }^{6}$ Communication with KOSKİ-Konya Water and Sewerage Authority.

${ }^{7}$ This cost includes: 1) the annual operation and maintanence cost, varying from TL0.5 to $2.5 / \mathrm{m}^{3}$, with an average of TL1.5/ $/ \mathrm{m}^{3}(\mathrm{a}) ; 2$ ) the annualized investment cost, estimated at TL0.3/ $/ \mathrm{m}^{3}$ (based on a total capital cost of TL145/capita, discharged quantity of 90 liters/capita/day, and lifetime of treatment plant of 20 years) (b). Adding up (a) and (b), the total annual cost of treatment is TL $1.8 / \mathrm{m}^{3}$. 
is the value that individuals place on the conservation of the lake's biodiversity, even though they may never use it directly.

No Contingent Valuation or Choice Experiment study has been found for Beyşehir Lake estimating this value. However, [13] valued non-users' WTP to conserve biodiversity in Cheimaditida Lake, a freshwater lake and Ramsar site in Greece. The authors used the Choice Experiment Method to account for people's preferences for biodiversity under different management scenarios. They estimated the non-users' WTP at 15.5 euro per person (2005 prices). Adjusting this estimate for Beyşehir Lake, a WTP for biodiversity is TL5/person for $2015^{8}$.

Beyşehir Lake is found at the border between the Konya and Isparta regions, whose population counts 2.5 million people [39]. By deducting the number of visitors to Beyşehir (327,900 people, see section 4.2), the total population of "non-users" that live in close proximity to the lake is estimated at 2.2 million. Assuming that they are willing to pay TL5/person for biodiversity conservation of Beyşehir Lake, the associated nonuse values linked to biodiversity are estimated at TL11 million. It should be stressed that this estimate has only indicative meaning, being based on values and assumptions from studies conducted in another country (Greece), due to a lack of specific data for the lake.

\subsection{The Total Economic Value}

Based on the above estimates, the estimated TEV of Beyşehir Lake reaches TL271 million in 2015. Direct use values account for more than $90 \%$ of the TEV, primarily due to the high value of water supply for agriculture and municipal uses (Figure 4). The indirect and non-use values account only for a small fraction of the TEV; this is mainly because a great part of these benefits are of intangible nature, which could not be estimated in monetary terms.

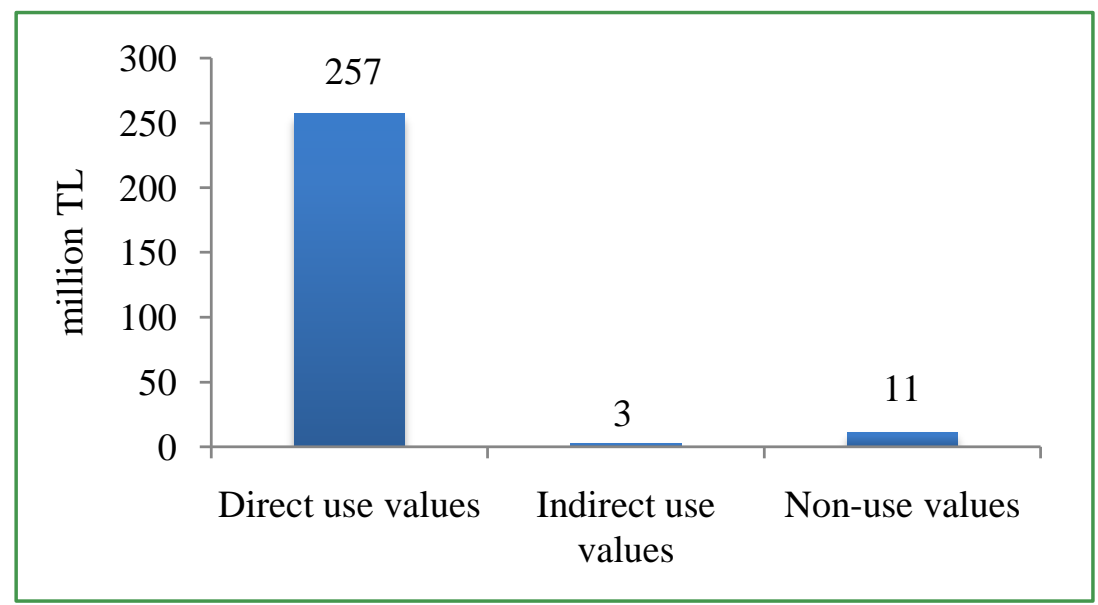

Figure 4. Estimated total economic value of Beyşehir Lake.

${ }^{8}$ The adjustment was done in two steps: 1) annualizing this value at a 3\% discount rate; 2) applying benefits transfer procedure, considering the GDP/capita ratio between the two countries and the consumer price index to reflect price differences between 2005 and 2015 . 


\section{Discussion}

Table 5 presents the main types of values provided by Beyşehir Lake. The second column shows that the estimated TEV represents 13\% of Beyşehir sub-catchment's GDP in $2015^{9}$. Considering the total population in the sub-catchment of 120,000 individuals, the economic value of Beyşehir Lake is about TL2300 per capita per year.

In absolute terms, the value of water for agriculture appears to be the most important component, followed by water for municipal use. However, this is because the quantity of water supplied for agriculture $\left(347\right.$ million $\left.\mathrm{m}^{3}\right)$ is much higher than that for municipal use $\left(11\right.$ million $\left.\mathrm{m}^{3}\right)$. However, the unit economic value of water allocated for municipal use ${ }^{10}\left(\mathrm{TL} 5 / \mathrm{m}^{3}\right)$ is considerably greater than that for irrigation ${ }^{11}\left(\mathrm{TL} 0.5 / \mathrm{m}^{3}\right)$. This result has important implications for policy in the basin.

Table 5, third column, presents the financial value of the lake, intended as actual revenues derived from the goods and services provided by the lake. These revenues include the tariffs paid for irrigation water, municipal water as well as the fees collected from visitors and sales of fishing licenses. A comparison between values shows that the economic value of water in Beyşehir Lake is nearly seven times higher than its financial

Table 5. Main types of values provided by Beyşehir Lake.

\begin{tabular}{|c|c|c|}
\hline TEV & Economic value (million TL) & Financial value $^{\mathrm{a}}$ (million TL) \\
\hline \multicolumn{3}{|l|}{ Direct use values } \\
\hline Water supply for irrigation & 186 & 10 \\
\hline Water supply for municipal use & 55 & 30 \\
\hline Recreation & 7 & 0.7 \\
\hline Wildlife and plant harvesting (fishing) & 9 & 0.04 \\
\hline \multicolumn{3}{|l|}{$\underline{\text { Indirect use values }}$} \\
\hline Nutrient retention & n.e. & 0 \\
\hline Pollution abatement & 3 & 0 \\
\hline Flood control & n.e. & 0 \\
\hline Micro-climatic stabilization & n.e. & 0 \\
\hline Option values & n.e. & 0 \\
\hline$\underline{\text { Non-use values }}$ & 11 & 0 \\
\hline Total & 271 & 41 \\
\hline Total (\% of Beyşehir’s GDP) & $13 \%$ & $2 \%$ \\
\hline
\end{tabular}

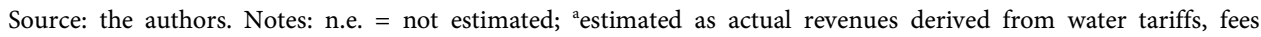
collected from visitors and sales of fishing licenses.

${ }^{9}$ The estimation was conducted as follows: the gross value added per capita in Konya-Karaman region was TL11,935 in 2011 [54]. Based on the total population of Beyşehir sub-catchment (120,000 people), the GDP of this area is estimated at TL1.43 billion in 2011. This represents $0.11 \%$ of Turkey's GDP of the same year. Considering the same ratio in the country's GDP for 2015, and knowing that Turkey's GDP is TL1953 billion in 2015 [55], the GDP of Beyşehir sub-catchment was estimated at TL2.16 billion in 2015.

${ }^{10}$ Obtained by dividing the economic value of water for municipal uses (TL55 million) by the quantity supplied $\left(11\right.$ million $\left.\mathrm{m}^{3}\right)$.

${ }^{11}$ Obtained by dividing the economic value of water for agriculture (TL186 million) by the quantity supplied (347 million $\mathrm{m}^{3}$ ). 
value. The gap between the two estimates is largely explained by the difference between the economic value of water supply for different uses (irrigation, municipal) and its financial value. In addition, the analysis demonstrates that the unit economic value of water is much higher than its financial value for both municipal (TL5 $/ \mathrm{m}^{3} \mathrm{vs}$. TL2.7/ $\mathrm{m}^{3}$ on average) and agricultural uses (TL0.5/ $\mathrm{m}^{3}$ vs. TL0.03/ $\left.\mathrm{m}^{3}\right)^{12}$. This result indicates that increasing tariffs could be potentially useful for water conservation in the sub-catchment.

It should be also stressed that despite these benefits, Beyşehir Lake is affected by several threats. Human factors (e.g. release of domestic and industrial pollutants, overfishing, over-abstraction of water) and natural influences (e.g. climate change) contribute to a reduction of its depth, which diminishes the value of biodiversity. A Contingent Valuation survey found that $37 \%$ of Beyşehir residents were willing to pay TL18/household/month in 2010 to improve the lake's water quality [28]. Although conservative, these results suggest the need to deal with the competitive uses of the lake in order to reduce the risk of depletion and pollution in the near future. On the positive side, the survey indicates that there is a certain awareness and willingness of local population to deal these problems.

\section{Conclusions and Recommendations}

The Turkish Government is considering adopting a set of policy issues related to water resource management, which address water's economic contribution to national growth, trade-offs among competing users in managing water resources, water pricing and cost recovery, as well as planning and prioritizing investments to compensate the loss of water due to depletion [48]. The need for water-related policy analysis and decisionmaking is a strong motivation for the development and application of water valuation and accounting tools. In this light, the Ministry of Development, the Turkish Statistical Institute and the Ministry of Forestry and Water Affairs are intent on conducting valuation to better understand water resources' economic contribution to the economy, improve water accounting, and integrate water valuation in water resources planning processes at the river basin level. In line with this interest, the present study provided a methodology to estimate the value of the economic benefits related to water, and applied it to estimate water benefits in a pilot area: Beyşehir Lake sub-catchment. As a rapid valuation exercise, the results of this study should be considered only rough approximations of the real value of water benefits provided by the lake. The study identified the need for the following actions:

\section{At the local level (Beyşehir Lake):}

$\checkmark$ The economic value of water provided by Beyşehir Lake is substantially higher than its financial value (US\$271 million vs. US\$41 million). At the same time, the lake is affected by competing uses (e.g. irrigated agriculture, fishing, municipal uses of

${ }^{12}$ The unit financial value of water in agriculture is obtained by dividing the total financial value of water in agriculture by the quantity used (TL10 million $/ 347$ million $\mathrm{m}^{3}=\mathrm{TL} 0.03 / \mathrm{m}^{3}$ ). Similarly, the unit financial value of water for municipal use is obtained by dividing the total financial value of water for municipal uses by the quantity supplied (TL30 million/11 million $\mathrm{m}^{3}=\mathrm{TL} 2.7 / \mathrm{m}^{3}$ ). 
water), which pose risks of depletion and pollution in the near future. This situation suggests an urgent need for conservation measures, which should encourage a more sustainable exploitation of water, and an improvement of valuable services such as recreation and biodiversity.

$\checkmark$ Water supply for agriculture appears to be the most important component, followed by water for municipal uses. However, the unit economic value of water allocated for municipal use $\left(\mathrm{TL} 5 / \mathrm{m}^{3}\right)$ is considerably greater than that for irrigation $\left(\mathrm{TL} 0.5 / \mathrm{m}^{3}\right)$. This suggests that water allocation among uses is inefficient. To validate this conclusion and improve allocation, a more comprehensive assessment of the economic benefits of water resources is required, focusing particularly on the value of water for irrigation, municipal use, recreation and biodiversity. A better understanding of the value of water in its various uses will help design systems that improve the total benefits of water by improving its allocation; the allocation experiences of other countries can provide a useful starting point for such efforts.

$\checkmark$ The existing estimates are based on secondary data, complemented by field interviews conducted during a short period of time. These estimates should be refined through new studies or field surveys. For example, the estimated value of water for agriculture could be improved by using results of more complex farm budgets that account not only for marketed inputs (e.g. cost of fertilizers, harvest), but also for non-priced ones (e.g. opportunity cost of time, as is the case of unpaid labor). Estimates of other benefits could be also refined, by conducting primary surveys in the lake's area. This is the case of the value of water for municipal use (e.g. by conducting Contingent Valuation studies to derive the users' WTP for municipal water), the value of recreation (e.g. by performing Travel Cost or Contingent Valuation surveys) and the value of biodiversity (e.g. by conducting Contingent Valuation or Choice Experiments studies).

\section{At the national level:}

$\checkmark$ High-level political will and commitment, particularly from the national Government, are fundamental to ensure that valuation is integrated into decision-making processes. Other measures are equally important, such as helping promote effective coordination among stakeholders by forming an Expert Advisory Group under the coordination of the Ministry of Development, comprised of experts and officials from relevant Government agencies (Turkish Institute of Statistics, Ministry of Forestry and Water Affairs, Ministry of Environment and Urbanization), academia and civil society organizations, in order to ensure that efforts related to Natural Capital Accounting and Valuation are effectively carried out inter-ministerially. It is therefore important to nurture the political will and institutional arrangements to support the incorporation of valuation into decision-making.

$\checkmark$ In Turkey, water valuation efforts have been uneven, concentrating mostly on valuing recreation and to a lesser degree on the purification function of water bodies. Little work has been found on the value of water for irrigation and municipal use, and none on indirect use values (e.g. flood control, pollution abatement) or the costs of water degradation (i.e. impacts of water pollution and overexploitation). 
Moreover, the existing studies have been concentrated in a few river basins. To better understand the importance of water resources and to be able to prioritize and design interventions there is a need for a more comprehensive set of studies that would cover both a wider range of values and a wider range of river basins.

$\checkmark$ Turkey is making efforts to prepare river basin management plans for 25 river basins aligned with the European Union-Water Framework Directive, with the main goal of reconciling economic development and ecosystem maintenance. In particular, the Turkish Government prioritizes water allocation planning in river basins with competing water uses. In this context, integrating water valuation into river basins management plans would provide critical knowledge that would help prioritize problems and find solutions for improved water management.

\section{Acknowledgements}

The authors gratefully acknowledge the financial and technical support for this study provided by the World Bank's Turkey Environment and Natural Resources Technical Assistance Program and the World Bank's Wealth Accounting and Valuation of Ecosystem Services (WAVES) Global Partnership program. Special thanks are given to Esra Arıkan, Glenn-Marie Lange, David Treguer, Tamara Sulukhia, Eavan O'Halloran, Mustafa Ugur Alver and Xavier Chauvot De Beauchene for their valuable comments.

\section{References}

[1] DSİ (2015) DSİ Activity Report 2015, Ankara.

[2] FAO. Turkey Water Report. http://www.fao.org/nr/water/aquastat/countries_regions/TUR/index.stm

[3] TUSIAD (2008) Water Management in Turkey: Problems and Recommendations, 2008. Istanbul.

[4] Petrie, R. and Taylor, L. (2007) Estimating the Value of Water Use Permits: A Hedonic Approach Applied to Farmland in the Southeastern United States. Land Economics, 83, 302-318. https://doi.org/10.3368/le.83.3.302

[5] Mallios, Z., Papageorgiu, A., Latinopoulous, D. and Latinopoulous, P. (2009) Spatial Hedonic Pricing Models for the Valuation of Irrigation Water. Global Nest Journal, 11, 575-582.

[6] North, J.H. and Griffin, C. (1993) Water Source as a Housing Characteristic: Hedonic Valuation and Willingness to Pay for Water. Water Resources Research, 29, 1923-1929. https://doi.org/10.1029/92WR02995

[7] Stone, J.C. and Whittington, D. (1984) Industrial Water Demands. In: Kindler, J. and Russell, C.S., Eds., Modelling Water Demands, Academic Press, London.

[8] Fleming, C. and Cook, A. (2008) The Recreational Value of Lake McKenzie, Fraser Island: An Application of the Travel Cost Method. Tourism Management, 29, 1197-1205. https://doi.org/10.1016/j.tourman.2008.02.022

[9] Chen, W., Hong, H., Liu, Y., Zhang, L., Hou, X. and Raymond, M. (2008) Recreation Demand and Economic Value: An Application of Travel Cost Method for Xiamen Island. China Economic Review, 15, 398-406. https://doi.org/10.1016/j.chieco.2003.11.001

[10] Nandagiri, J. (2015) Evaluation of Economic Value of Pilikula Lake Using Travel Cost and 
Contingent Valuation Methods. Aquatic Procedia, 4, 1315-1321.

https://doi.org/10.1016/j.aqpro.2015.02.171

[11] Harrison, D.M., Smersh, G.T. and Schwartz, A.L. Jr. (2001) The Environmental Determinants of Housing Prices: The Impact of Flood Zone Status. Journal of Real Estate Research, 21, 3-20.

[12] Schultz, S.D. and Fridgen, P.M. (2001) Floodplains and Housing Values: Implications for Flood Mitigation Projects. Journal of the American Water Resources Association, 37, 595603. https://doi.org/10.1111/j.1752-1688.2001.tb05496.x

[13] Birol, E., Karousakis, K. and Koundouri, P. (2006) Using a Choice Experiment to Account for Preference Heterogeneity in Wetland Attributes: The Case of Cheimaditida Wetland in Greece. Ecological Economics, 60, 145-156. https://doi.org/10.1016/j.ecolecon.2006.06.002

[14] Birol, E., Koundouri, P. and Kountouris, Y. (2008) Integrating Wetland Management into Sustainable Water Resources Allocation: The Case of Akrotiri Wetland in Cyprus. Journal of Environmental Planning and Management, 51, 37-53. https://doi.org/10.1080/09640560701712259

[15] Birol, E., Koundouri, P. and Kountouris, Y. (2010) Assessing the Economic Viability of Alternative Water Resources in Water-Scarce Regions: Combining Economic Valuation, Cost-Benefit Analysis and Discounting. Ecological Economics, 69, 839-847. https://doi.org/10.1016/j.ecolecon.2009.10.008

[16] Liu, J. and Huijin, L.V. (2012) Economic Value of Water Resources of the Upper Reaches of the Xin'an River Basin, China. Journal of Resources and Ecology, 3, 87-92.

https://doi.org/10.5814/j.issn.1674-764x.2012.01.013

[17] Kakuru, W., Turyahabwe, N. and Mugisha, J. (2013) Total Economic Value of Wetlands Products and Services in Uganda. The ScientificWorld Journal, 2013, Article ID: 192656. https://doi.org/10.1155/2013/192656

[18] World Bank (2007) République Tunisienne. Evaluation du Coût de la Dégradation de l'Eau. Rapport No. 38856-TN, Washington DC.

[19] Tentes, G. and Damigos, D. (2012)The Lost Value of Groundwater: The Case of Asopos River Basin in Central Greece. Water Resource Management, 26, 147-164. https://doi.org/10.1007/s11269-011-9910-2

[20] Groom, B. and Kondouri, P. (2011) The Economics of Water Resource Allocation: Valuation Methods and Policy Implications. https://mpra.ub.uni-muenchen.de/id/eprint/41902

[21] Ortaçeşme V., Özkan, B. and Karagüzel, O. (2001) An Estimation of the Recreational Use Value of Kursunlu Waterfall Nature Park by the Individual Travel Cost Method. Turkish Journal of Agriculture and Forestry, 26, 57-62.

[22] Başar H. (2007) The Recreational Use and The Economic Value of Dilek Peninsula-Great Meander Delta National Park by Travel Cost Method, Ministry of Environment and Forestry. Directorate of Aegean Forestry Research, Izmir.

[23] Demir, A. (2014) Recreational Use Value of Tuz Lake in Turkey. Journal of Food, Agriculture \& Environment, 12, 1092-1096.

[24] Birdir, S., Özlem, Ü., Birdir K. and Williams, A.T. (2013) Willingness to Pay as an Economic Instrument for Coastal Tourism Management: Cases from Mersin, Turkey. Tourism Management, 36, 279-283. https://doi.org/10.1016/j.tourman.2012.10.020

[25] Blakemore, B., Williams, A., Coman, C., Micallef, A. and Unai, O. (2002) A Comparison of Tourist Evaluation of Beaches in Malta, Romania and Turkey. World Leisure Journal, 44, 29-41. https://doi.org/10.1080/04419057.2002.9674268 
[26] Blakemore, F. and Williams, A. (2008) British Tourists' Valuation of a Turkish Beach Using Contingent Valuation and Travel Cost Methods. Journal of Coastal Research, 24, 14691480. https://doi.org/10.2112/06-0813.1

[27] Gürlük, S. and Rehber, E. (2006) A study on Environmental Valuation of Lake Manyas. Journal of Agricultural Economics, 15, 9-15.

[28] Ozdemir, F.Y. and Baycan-Levent, T. (2010) A Contingent Valuation Approach to Community-Based Watershed Management in Beyşehir Lake Basin. 50 th Congress of the European Regional Science Association: Sustainable Regional Growth and Development in the Creative Knowledge Economy, Jönköping, 19-23 August 2010.

[29] Tolun, L., Ergenekon, S., Murat Hocaoglu, S., Suha Donertas, A., Cokacar, T., Husrevoglu, S., Polat Beken, C. and Baban, A. (2012) Socioeconomic Response to Water Quality: A First Experience in Science and Policy Integration for the Izmit Bay Coastal System. Ecology and Society, 17, 40 .

[30] Can, Ö. and Alp, E. (2012) Valuation of Environmental Improvements in a Specially Protected Marine Area: A Choice Experiment Approach in Göcek Bay Turkey. Science of Total Environment, 439, 291-298. https://doi.org/10.1016/j.scitotenv.2012.09.002

[31] Tsur, Y. (2004) Pricing Irrigation Water in Turkey. In: Tsur, Y., Terry, R., Doukkali, R. and Dinar, A., Eds., Pricing Irrigation Water. Principles and Cases from Developing Countries, RFF Press, Washington DC.

[32] Aydogdu, M. (2016) Evaluation of Willingness to Pay for Irrigation Water: Harran Plain Sampling in GAP Region, Turkey. Applied Ecology and Environmental Research, 14, 349365. https://doi.org/10.15666/aeer/1401_349365

[33] Tilmant, A., Pinte, D. and Goor, Q. (2008) Assessing Marginal Water Values in Multipurpose Multireservoir Systems via Stochastic Programming. Water Resources Research, 44, Article ID: W12431. https://doi.org/10.1029/2008WR007024

[34] Bilgic, A., Eren,G. and Florkowski, W. (2008) Willingness to Pay for Potable Water in the Southeastern Turkey: An Application of both Stated and Revealed Preferences Valuation Method. 2008 Annual Meeting, Dallas, 2-6 February 2008.

[35] Gürlük, S. and Ward, F. (2009) Integrated Basin Management: Water and Food Policy Options for Turkey. Ecological Economics, 68, 2666-2678.

https://doi.org/10.1016/j.ecolecon.2009.05.001

[36] Gürlük, S. (2010) Economic Value of an Environmental Management Plan: Case of Uluabat Lake. Journal of Biology and Environmental Sciences, 4, 59-65.

[37] Ministry of Environment and Forestry (2010) TUBİTAK-MAM. Konya Closed Basin Protection Action Plan Final Report, Ankara.

[38] Nas, B., Ekercin, S., Karabörk, H., Berktay, A. and Mulla, D. (2010) An Application of Landsat-5TM Image Data for Water Quality Mapping in Lake Beyşehir, Turkey. Water Air Soil Pollution, 212, 183-197. https://doi.org/10.1007/s11270-010-0331-2

[39] TurkStat (2014) Address Based Population Registration System. www.tuik.gov.tr

[40] Alaş, A., Altındag, A., Yılmaz, M., Kırpık, M. and Ak, A. (2010) Feeding Habits of Tench (Tinca tinca L., 1758) in Beyşehir Lake (Turkey). Turkish Journal of Fisheries and Aquatic Sciences, 10, 187-194. https://doi.org/10.4194/trjfas.2010.0205

[41] Turner, K. and Schaafsma, M. (Eds.) (2015) Coastal Zones Ecosystem Services: From Science to Values and Decision. Springer, Berlin.

[42] Brouwer, R., Barton, D., Bateman, I., Brander, L., Georgiou, S., Martín-Ortega, J., Navrud, S., Pulido-Velazquez, M., Schaafsma, M. and Wagtendonk, A. (2009) Economic Valuation of Environmental and Resource Costs and Benefits in the Water Framework Directive: 
Technical Guidelines for Practitioners. EU Funded Project Aqua Money.

[43] Young, R. and Loomis, J.B. (2014) Determining the Economic Value of Water: Concepts and Methods. 2nd Edition, RFF Press, New York.

[44] Barbier, E. B. (2007) Valuing Ecosystem Services as Productive Inputs. Economic Policy, 22, 177-229. https://doi.org/10.1111/j.1468-0327.2007.00174.x

[45] Navrud, S. and Ready, R. (2007) Environmental Value Transfer: Issues and Methods. Springer, Berlin. https://doi.org/10.1007/1-4020-5405-X

[46] Johnston, R.J., Rolfe, J., Rosenberger, R.S. and Brouwer, R. (2015) Benefits Transfer of Environmental and Resource Values: A Guide for Researchers and Practitioners. Springer, Berlin. https://doi.org/10.1007/978-94-017-9930-0

[47] Mendelsohn, R. and Olmstead, S. (2009) The Economic Valuation of Environmental Amenities and Disamenities: Methods and Applications. Annual Review of Environment and Resources, 34, 325-347. https://doi.org/10.1146/annurev-environ-011509-135201

[48] Croitoru, L., Divrak, B., Xie, J. and Arikan, E. (2016) Valuing Water Resources in Turkey: A Methodological Overview and Case Study. World Bank, Washington DC.

[49] TurkStat (2015) Crop Production Statistics. www.tuik.gov.tr

[50] Konya Commodity Exchange (2015) www.ktb.org.tr

[51] Konya Provincial Directorate of Agriculture (2015) Farm Budget of Irrigated Lands for Konya.

[52] Scandizzo, P. and Abbasov, R. (2012) The Value of Water in the Greater Baku Area: An Integrated Water Management Study. World Bank, Washington DC.

[53] Babaoğlu, M. (2007) Final Report of the Commission Established for Analysing the Beyşehir Lake's Problems and Measures.

[54] Turkstat (2011) Gross Value Added Per Capita by Classification of Statistical Regional Units, Level 2, 2004-2011.

[55] Turkstat (2016) Gross Domestic Product. http://www.tuik.gov.tr/PreHaberBultenleri.do?id=21511

Submit or recommend next manuscript to SCIRP and we will provide best service for you:

Accepting pre-submission inquiries through Email, Facebook, LinkedIn, Twitter, etc.

A wide selection of journals (inclusive of 9 subjects, more than 200 journals)

Providing 24-hour high-quality service

User-friendly online submission system

Fair and swift peer-review system

Efficient typesetting and proofreading procedure

Display of the result of downloads and visits, as well as the number of cited articles

Maximum dissemination of your research work

Submit your manuscript at: http://papersubmission.scirp.org/

Or contact jep@scirp.org 